\title{
Integrating tree-ring and inventory-based measurements of aboveground biomass growth: research opportunities and carbon cycle consequences from a large snow breakage event in the Swiss Alps
}

\author{
S. Klesse ${ }^{1,2} \cdot$ S. Etzold ${ }^{1}$ D. Frank Fr, $^{1,2}$
}

Received: 27 April 2015/Revised: 20 December 2015/ Accepted: 25 December 2015/Published online: 9 January 2016

(C) Springer-Verlag Berlin Heidelberg 2016

\begin{abstract}
The temporal variability of the forest sink is associated with high uncertainties in both its magnitude and the driving ecological and climatic processes. In this study, we assess the inter-annual variability (IAV) of carbon uptake using annually resolved aboveground biomass increment (ABI) estimates from 272 pseudorandomly sampled trees at a long-term monitoring plot in the dry valley of the Valais in Switzerland. Over the 1950-2011 period, the mean ABI is $86.8 \mathrm{~g} \mathrm{C} \mathrm{m}^{-2}$ year $^{-1}$ with an IAV of $\pm 31 \%$. The IAV is largely driven by hydrological conditions throughout the water year from previous August to current August $\left(r_{\mathrm{SPEI}}=0.56 ; 1\right.$ st differenced $r=0.75$, $p<0.001$ ). During extremely dry years (such as 1972, 1976, 1998, and 2011), the carbon accumulation was reduced up to $63 \%$ from the long-term mean. Furthermore, our analysis explores possible biases of annual ABI derived from manual band dendrometers in permanent plot inventories caused by water status related changes in tree size. During the snow breakage event in March 2012 and subsequent management activities, $17 \%$ of the standing biomass was killed. We estimate that the remaining trees will take $\sim 16$ years to make up for the loss of this disturbance,
\end{abstract}

Handling editor: Lluís Coll.

Electronic supplementary material The online version of this article (doi:10.1007/s10342-015-0936-5) contains supplementary material, which is available to authorized users.

S. Klesse

Stefan.klesse@wsl.ch

1 Swiss Federal Research Institute WSL, Zürcherstrasse 111, 8903 Birmensdorf, Switzerland

2 Oeschger Centre for Climate Change Research, 3012 Bern, Switzerland assuming a similar growth rate of the remaining trees as during the previous 60 years and that a potentially drier climate and the increased water availability for the remaining trees will balance each other. We demonstrate that well-replicated, representative tree-ring datasets have a huge potential to complement shorter-term and lower-resolution forest inventory monitoring data. Integrating treering and plot data allow one to gain knowledge about annual changes in forest productivity even before monitoring started and help ecosystem managers to better adapt their strategies.

Keywords Dendrochronology - Aboveground biomass increment · Interannual variability · Drought $\cdot$ Disturbance

\section{Introduction}

Forests cover around $30 \%$ of the terrestrial surface and contribute $1.1 \pm 0.8 \mathrm{pg} \mathrm{C}$ per year to the total terrestrial carbon sink (Pan et al. 2011), which was recently estimated at $2.9 \pm 0.8$ pg C (Le Quéré et al. 2015). Forests mitigate approximately $30 \%$ of all $\mathrm{CO}_{2}$ emissions from fossil fuel burning and land-use changes (Canadell and Raupach 2008; Friedlingstein et al. 2010) and thereby dampen the magnitude of global warming. However, the temporal variability of the forest sink remains poorly quantified and is associated with high uncertainties in both its magnitude and driving ecological and climatic processes (Poulter et al. 2014). Projected gradual environmental change and impacts from climate extreme events such as droughts are expected to heavily affect the magnitude of the forest carbon sink in the future (Nemani et al. 2003; Beer et al. 2010; Reichstein et al. 2013; Zscheischler et al. 2014). Carbon stocks in regions already prone to drought under 
current climate conditions will likely decrease, e.g., through increased mortality (Allen et al. 2010), while forests at the upper timberline are expected to benefit from the projected climate change, e.g., through prolongation of the growing season (Jolly et al. 2005; Manusch et al. 2014). Severe droughts can cause more than a 2 standard deviation reduction in carbon uptake, as reported by Bastos et al. (2014) for the 2003 and 2010 heat waves in Europe and can even cause some forests being a short-term carbon source (Ciais et al. 2005).

The increased likelihood and severity of future disturbances such as wind throws, insect outbreaks, and wildfires will also reduce the carbon accumulation rates and storage in forests (Seidl et al. 2014). For example, in 1999 the heavy winter storm Lothar (the most destructive storm on record in Europe) caused an approximate $30 \%$ reduction of the net annual carbon increase in central Europe through soil disturbance and reduced productivity following the storm (Lindroth et al. 2009). In France, the country most affected by this storm, approximately $8.4 \%$ of growing stock were lost (Gardiner et al. 2010). After storm events or during insect outbreaks, the resulting local or widespread tree damage and mortality reduce forest carbon uptake, increase future emissions from the decay of killed trees, and can turn forests from a net carbon sink to a longer-term carbon source (Kurz et al. 2008), probably counteracting climate change mitigation policies (Le Page et al. 2013; Nabuurs et al. 2013). Furthermore, the coupled effects of climate change and intensifying disturbance regimes might negatively affect timber based forest economy (Hanewinkel et al. 2013), also through increasing management costs related to salvage logging or fire suppression (Gardiner et al. 2010).

To place ongoing trends and predictions of tree and forest growth performance into the context of past variability, annually resolved tree-ring measurements can be regarded as a primary tool. Tree-ring data have been previously used for a variety of research fields ranging from climate reconstructions (Esper et al. 2014; Frank et al. 2010), forest ecology studies (Esper et al. 2007; Svoboda et al. 2014), archeological dating (Martin-Benito et al. 2014) to reconstructions of geomorphic activity (Gärtner et al. 2004; Stoffel and Corona 2014). Tree-rings are a direct measure of radial stem growth, which is closely linked to annual wood formation and carbon accumulation (Bouriaud et al. 2005; Kerhoulas and Kane 2012). In combination with appropriate allometric equations (e.g., Zianis et al. 2005), these data can contribute to better understand the dynamics of ecosystem processes in a longterm context, preceding remote sensing data from satellites and improving the resolution of forest inventory campaigns (Metsaranta and Lieffers 2009; Etzold et al. 2014; Zingg 1996; Pretzsch et al. 2014). We are aware that the transformation of tree-ring width (TRW) to aboveground biomass increment $(\mathrm{ABI})$ introduces uncertainties related to the allometric equations, but this step allows comparison of absolute quantities of ABI, firstly among sites, and secondly with other carbon cycle data streams such as inventories, eddy covariance measurements, remote sensing data, and vegetation model results.

In this study, we aim to quantify the inter-annual variation (IAV) of ABI on a long-term monitoring site in Switzerland. The study site is situated in an inner alpine dry valley, a region where drought-induced pine mortality and potential species range shifts have been a hot research topic over the past years (Eilmann et al. 2006; Bigler et al. 2006; Weber et al. 2007). The site was hit by a severe snow storm event in late winter of 2011/2012 providing us with the opportunity to contextualize storm-induced mortality with biomass accumulation rates. Furthermore, we sought to compare annually resolved TRW-based with lower resolved inventory-based ABI estimates to establish foundations to improve carbon balance accounting schemes. Analysis of the dataset was performed to answer the research questions: (1) How well do TRW and inventoryderived ABI estimates agree with each other? (2) What is the main climatic driver of tree growth, and how much do climatic extremes reduce or enhance aboveground biomass increment at this site? and (3) How long does it take for the remaining trees to make up for the loss of this snow storm event? Due to the well-replicated nature of this dataset, we further test the reliability of tree-ring width to basal area increment (BAI) and ABI transformations and also explore the implications of standard dendrochronological field practices to obtain robust estimates of annual carbon accumulation.

\section{Materials and methods}

\section{Study site}

Our study was conducted at a long-term monitoring site in Switzerland, which is part of the Swiss "Long-term Forest Ecosystem Research Programme" (LWF). The research plot is located at $1060 \mathrm{~m}$ a.s.l. in the inner alpine dry valley of Valais in southwestern Switzerland close to the village Lens. The site climate is moderate with a mean annual temperature of $8.1{ }^{\circ} \mathrm{C}$ and $969 \mathrm{~mm}$ total precipitation (Fig. 1). The soil is a shallow Haplic Calcisol with an average slope of $75 \%$ toward southeast. Monitoring parameters from the LWF program include data on tree species, social class and spatial position, 5-yearly to annual measurements of $\mathrm{DBH}$, height and crown transparency, and site-specific information including data on meteorology, litter fall, and soil water content since 1995 (Thimonier et al. 2011). 
(a)

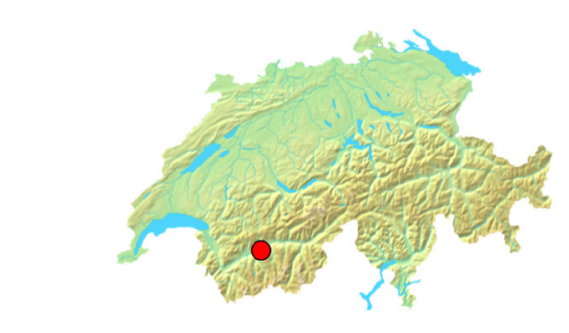

(b)

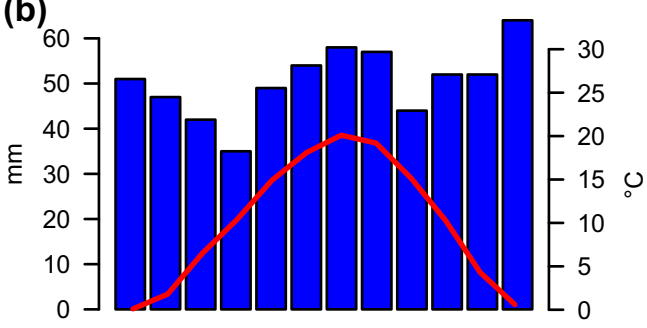

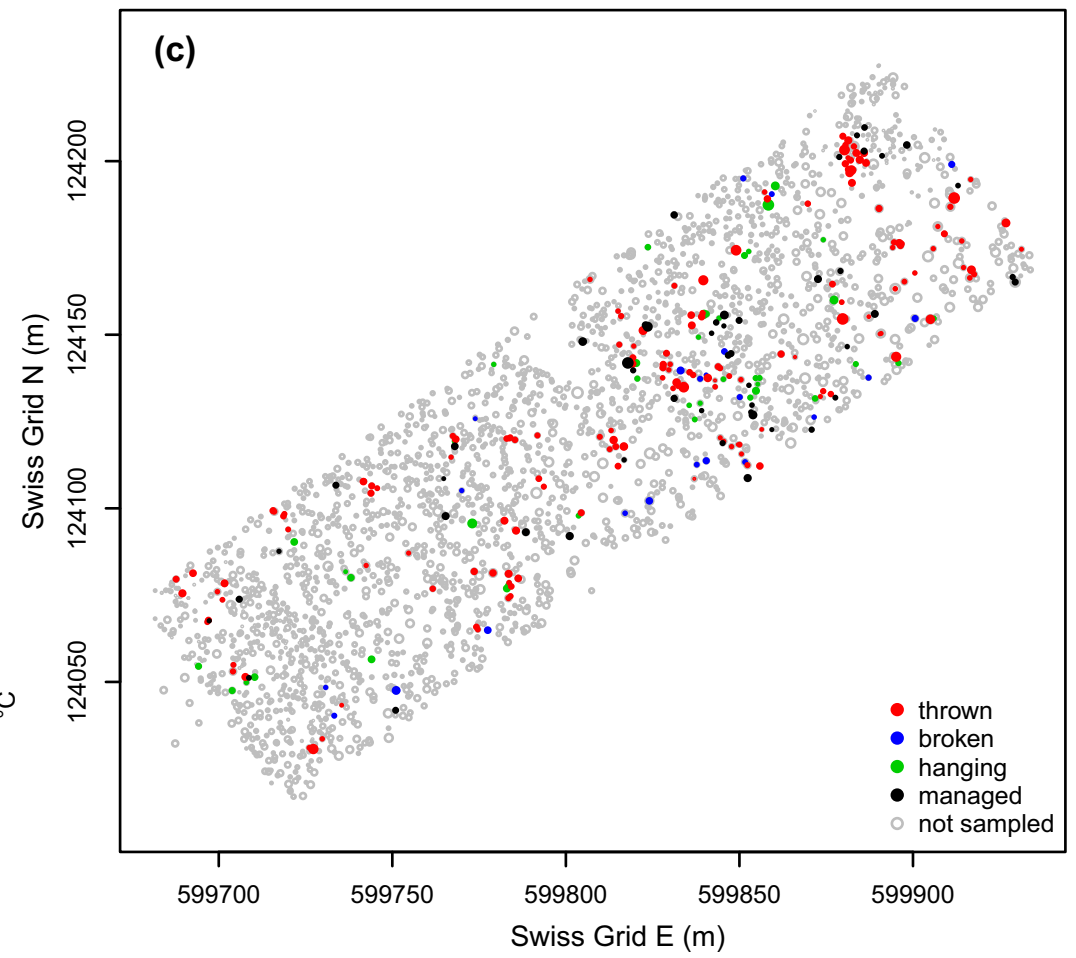

(filled circles) inside the LWF long-term monitoring plot. During the inventory after the snow-break, the trees have been classified as either thrown (red), broken (blue), hanging (green) or without any initial wind damage (black). (Color figure online)

and ranges from $0 \%$ (optimal foliage) to $100 \%$ transparency (fully defoliated; Dobbertin 2005). Multiple crown transparency measurements per tree were averaged to achieve a mean crown transparency value for the 1996-2010 period. From 2001 on, the DBH of 10 pines selected using a stratified random design (Dobbertin 2005) were read annually with permanently installed circumference bands. The individual derived increments were transformed to relative values of the inventory mean increment of the respective tree, averaged, and are expressed as the annual band-dendrometer index (Etzold et al. 2014). In 2010 the LWF site consisted of 2775 trees, including 324 dead individuals.

Following a massive snow storm in early 2012, an extra inventory of the site was performed in May 2012 prior to a management intervention. This inventory revealed that during the snow breakage event 201 trees fell down or broke below $1.30 \mathrm{~m}$ (hereafter classified as thrown). Only 5 of the 201 trees were recorded as dead in the last regular inventory 1 year earlier. Ninety-nine trees either broke completely above $1.30 \mathrm{~m}$ or had a severe loss of branches in the crown (all of these trees were alive in previous inventory). Ninety-seven trees were hanging or leaning in other trees (only one of these was dead in the previous inventory). We subsequently sampled stem disks from 320 1999. Crown transparency is an indicator for tree health 
trees at breast height $(1.30 \mathrm{~m})$ of which 272 trees could be unambiguously identified. Of the identified trees 159 samples belonged to thrown trees, 22 to broken, 42 to hanging, and another 49 samples collected from trees cut in the subsequent management efforts. This dataset represents approximately $10 \%$ of the whole population on the 2-ha plot. The sampled trees are distributed across the entire plot and may for all intents and purposes be considered a random sampling. Yet, there are "hot spots" where the samples spatially cluster due to cascade effects of the first broken tree and management surrounding the damage zone (Fig. 1). Tests for the representativeness of our dataset were performed by 500 Monte Carlo-type replicates of 272 randomly chosen trees from the entire inventory.

\section{Tree-ring data}

The stem disks were sanded, scanned (900-1200 dpi), and measured with WinDendro to the nearest $0.001 \mathrm{~mm}$ (Regent Instruments). Per disk we measured 4 radii; two radii parallel to the slope and one for each the uphill and downhill sides. Samples were visually and statistically crossdated with COFECHA (Holmes 1983) and quality checked following standard dendrochronological procedures. If exact dating was hampered by locally absent rings (typically the outermost rings of suppressed or stressed individuals due to partial cambial mortality preceding crown mortality; Wilmking et al. 2012; Bigler and Rigling 2013), the length of the problematic segment was measured, divided by the number of estimated years, and filled in as an average growth rate.

We applied two different standardization techniques to the mean of the 4 radii to remove non-climatic trends in the tree-ring width (TRW) measurements, a spline detrending with a $50 \%$ frequency-response threshold of 32 years (Cook and Peters 1981) and regional curve standardization (RCS; Briffa and Melvin 2011). In RCS, the individual series are first aligned by cambial age to obtain a regional growth curve (i.e., a population estimate for the age trend) which is then used to detrend the individual series. RCS allows the preservation of lower frequencies in the tree-ring data, while removing the site-specific age-related trends. After averaging the single series with Tukey's biweight robust mean, the variance was stabilized to minimize variance artefacts from changes in sample replication (Osborn et al. 1997; Frank et al. 2006). To account for long-term changes of stand growth, the BA and BAI were calculated for each single radius, the two slope-parallel radii and for all four radii together, according to the formula:

$\mathrm{BAI}=\pi\left(R_{t}^{2}-R_{t-1}^{2}\right)$,

where $R$ is the tree radius and $t$ the year the ring was formed. The ring-width-based BA measurements were compared against the true wood area from the scanned image (Image-Pro Plus, Media Cybernetics) to test the representativeness of the ring width measurements. We linearly regressed the cumulative sum of the four averaged radii of 2010 against the inventory-based $\mathrm{DBH}$ measurements of 2010 to obtain a correction factor for the $\mathrm{DBH}$ reconstruction (average radius without bark to diameter with bark), which is needed for ABI calculation with allometric equations. We also tested whether this correction factor is constant over the previous three inventories.

\section{Calculation of aboveground woody biomass increment}

We used volume and mass equations for stem, branches, and twigs from species- and region-specific allometric relationships as applied by the Swiss national forest inventory (NFI) (Brassel and Lischke 2001). The DBH was reconstructed by averaging all measured radii (inside bark) and applying an outside bark correction factor of 2.41 (derived from the 2010 inventory) to each measurement.

$\mathrm{DBH}=$ radius $_{\mathrm{avg}} \times 2.41, R^{2}=0.9978$

As the allometric volume equation requires tree height (for every year back in time), we developed a relationship between height and DBH based upon the inventories in 1995, 1999, 2005, and 2010. For this purpose, a logarithmic model according to Etzold et al. (2014) was applied:

Height $=-2.26+4.558 \times \log (\mathrm{DBH}), R^{2}=0.45$

The unexplained variance can be attributed to the high spread around the mean, which is probably caused by water limitation and competition (Etzold et al. 2014). However, the residuals of the DBH height model are unbiased and homoscedastic, so that over- and underestimations of small and tall trees should cancel each other out throughout the height reconstruction. To ensure reconstructed tree heights were positive even at the smallest DBH classes, for trees with a $\mathrm{DBH}<5 \mathrm{~cm}$, we replaced the logarithmic model with a straight line:

Height $_{<5 \mathrm{~cm}}=1.3+0.76 \times \mathrm{DBH}$

Aboveground wood volume was calculated separately for stem (Vstem), branches (Vbranch), and twigs (Vtwig) as a function of the reconstructed DBH in (1) and modeled height (2) according to Kaufmann (2001) and further developed by Kaufmann (personal communication) with:

$$
\begin{aligned}
\text { Vstem }= & a_{0}+a_{1} \times \text { height model } \mathrm{DBH}^{2}+a_{2} \\
\times & \text { height model } \times \mathrm{DBH}^{3} \\
\text { Vbranch }= & \text { Vstem } \times \exp \left(b_{0}+b_{1} \times \mathrm{DBH}\right) / 1 \\
& +\exp \left(b_{0}+b_{1} \times \mathrm{DBH}\right)
\end{aligned}
$$




$$
\begin{aligned}
\text { Vtwig }= & \text { Vstem } \times \exp \left(t_{0}+t_{1} \times \mathrm{DBH}\right) / 1 \\
& +\exp \left(t_{0}+t_{1} \times \mathrm{DBH}\right)
\end{aligned}
$$

To convert from wood volume to wood biomass, the wood density value of $510 \mathrm{~g} / \mathrm{cm}^{3}$ was used (Etzold et al. 2014). This value was obtained during a sampling campaign in 2009 and is considerably higher than the value used by the NFI $\left(420 \mathrm{~g} / \mathrm{cm}^{3}\right.$, Brändli 2010). A constant proportion of $50 \%$ carbon per $\mathrm{kg}$ of dry biomass was applied (Joosten et al. 2004). Upscaling of the subset to the full 2 ha of the monitoring plot was performed by multiplying our increment data by 9.96 . This value reflects the proportion of the unsampled trees of all four inventories to the subset of 272 trees.

\section{Meteorological data}

To investigate the climate response of tree growth, monthly temperature and precipitation data as well as the Standardized Precipitation-Evaporation Index (SPEI, Vicente-Serrano et al. 2010) were obtained from the nearest gridbox of the CRU TS 3.21 dataset $\left(46.25^{\circ} \mathrm{N}\right.$, $7.25^{\circ} \mathrm{E}$, Harris et al. 2014). The SPEI is a multi-scalar drought index and calculated as the standardized difference between precipitation and potential evapotranspiration. All chronologies were correlated against monthly averaged climate data starting from previous January to current October. Monthly values were further averaged to seasonal windows up to 18 months thereby integrating the most meaningful months for wood formation. Correlations were computed over the 1950-2011 period to avoid the juvenile-phase-related increase in the $\mathrm{BAI}$ and $\mathrm{ABI}$ chronologies. We tested the temporal stability of the climate-growth response by additionally computing the correlations with the detrended TRW chronologies over the full 1901-2011 period.

To investigate the direct reaction of tree growth to the best climate predictor (SPEI13 ${ }_{\text {August }}$ ), annual increment data of all individual trees were stratified according to their size classes $(0-7.5,7.5-15,15-22.5,22.5-30 \mathrm{~cm})$, as well as the SPEI data (centered around $-2,-1,0,1$ and 2). We performed a Wilcoxon test to calculate the statistical significance of differences between the growth levels of the same growth classes during different SPEI indexes. Additionally, we used daily water vapor pressure deficit (VPD) from the nearest meteorological station (Sion, Meteoswiss) to evaluate its possible relationship with the annual banddendrometer Index. VPD has been shown to influence the diurnal cycle of plant internal water status, with high VPD negatively affecting tree diameter (Zweifel et al. 2006, King et al. 2013).

\section{Results}

\section{Single radius/multiple radii versus true wooden area}

The regression slopes of the radius to DBH conversion are similar along the four inventories (2.41-2.432) and constant among all size classes. This points to a constant bark to wood ratio over the entire life span/size span of $P$. sylvestris. The best agreement between true wooden area from the scanned disk and the tree-ring-based basal area was achieved $\left(R^{2}=0.981\right)$, when all four radii were used (Fig. 2). Using all four radii resulted in a slight but negligible median underestimate of $0.8 \%$ (MAD $= \pm 2.7 \%$, $p=0.92$ ) compared to the scanned BA. Measurements based on the two slope-parallel radii, i.e., following standard sampling protocols, yielded also quite good agreement; however, a mean underestimation of actual wood of $5 \%$ would have occurred $\left(R^{2}=0.949, \mathrm{MAD}= \pm 9.7 \%\right.$, $p=0.36$ ). The basal areas inferred from only the downhill or uphill radius would have yielded a $40 \%$ overestimation or a $28 \%$ underestimation, respectively. All further calculations are thus based on the averages of all 4 radii, transformed to $\mathrm{BAI}$ or $\mathrm{ABI}$.

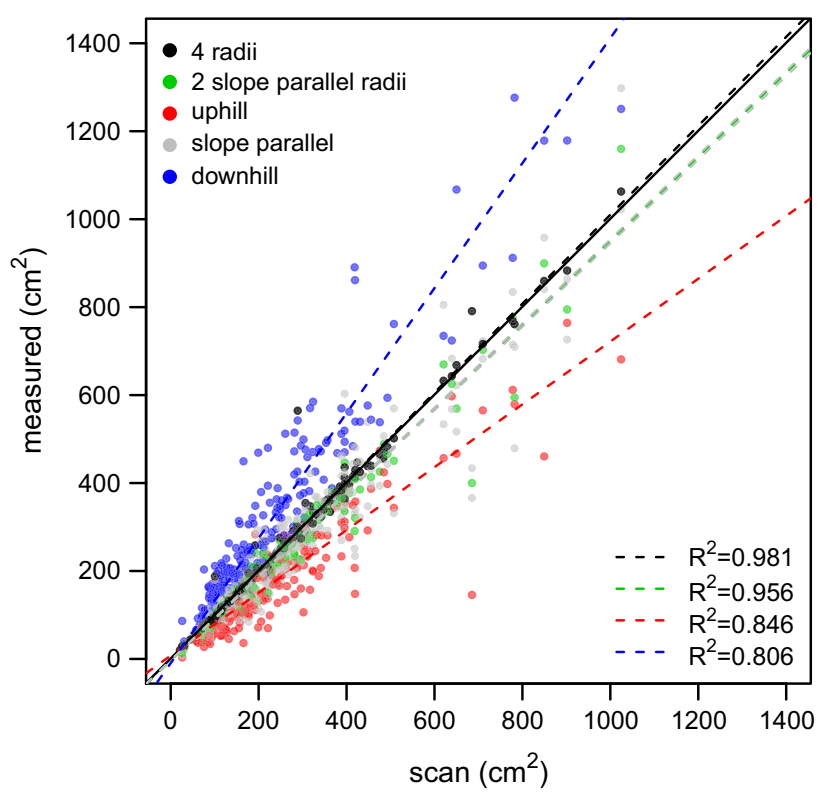

Fig. 2 Tree-ring based basal area plotted against true wooden area from the scanned image. Basal area calculations based on all 4 radii are shown in black, based on the two slope-parallel radii in green, uphill in red, downhill in blue and based on a single slope-parallel radius in gray. The full black line shows the 1:1 line; dashed lines are regression slopes for the individual combinations. (Color figure online) 


\section{Comparison of growth of different tree classes (DBH, height, crown transparency, social status)}

Our dataset of 272 identified trees revealed no significant deviation in $\mathrm{DBH}$, height, or social class distribution from the full 1999 inventory (Fig. 3; Table 1). Considering trees of all social classes, the overall average growth rate (BAI) from 1950 to 2011 was $4.04 \mathrm{~cm}^{2}$ year $^{-1}$. Dominant trees on average grew $9.17 \mathrm{~cm}^{2}$ year ${ }^{-1}$, which is more than twice as fast as codominant $\left(4.20 \mathrm{~cm}^{2}\right.$ year $\left.{ }^{-1}\right)$, nearly three times faster than dominated $\left(3.13 \mathrm{~cm}^{2}\right.$ year $\left.{ }^{-1}\right)$ and four times more than suppressed trees $\left(2.17 \mathrm{~cm}^{2}\right.$ year ${ }^{-1}$, Fig. 4). IAV as quantified by the coefficient of variation was rather constant among the four social classes $(30.1 \% / 30.3 / 28.5 / 29.7)$. During the three inventory periods (1996-2010), the mean growth rate of all trees was $4.10 \mathrm{~cm}^{2}$ year ${ }^{-1}$, which is very similar to the growth rate observed over the past 62 years. Also within the social classes, growth rate stayed on the same level $(9.14,4.23,2.73$, and $2.37 \mathrm{~cm}^{2}$ year ${ }^{-1}$, respectively). There was a significant positive relationship between growth rate and $\mathrm{DBH}$ $\left(\mathrm{BAI}_{\text {mean }}=-2.01+0.34 \times \mathrm{DBH}, R^{2}=0.69, p<0.001\right)$ as well as height $\left(\mathrm{BAI}_{\text {mean }}=-2.28+0.63 \times\right.$ height, $\left.R^{2}=0.26, p<0.001\right)$. With increasing crown transparency, there was the tendency to have lower growth rates. However, due the underrepresentation of trees with high crown transparency, these regressions were nonsignificant $(p>0.10)$.

\section{Stand history}

A major stand-level event occurred in 1914/1915 (Fig. 4). Trees living at this time showed a large growth release, with a large increase in the number of trees reaching breast height in the 1920-1930's, when the sample replication increases from 40 to over 200. Prior to the growth release (1900-1914), the growth rate of the presently dominant trees was similar to growth rates of the current codominant trees $\left(4.31 \mathrm{~cm}^{2}\right.$ year $\left.{ }^{-1}\right)$. The current codominant and dominated trees were likely suppressed during this 1900-1914 period with growth rates of 2.35 or $1.22 \mathrm{~cm}^{2}$ year $^{-1}$, respectively. The stand was more or less fully developed between 1940 and 1950 as evidenced by the sample replication curve flattening out. In 1977 several trees showed an abrupt growth increase and grew more than twice as fast in the following 20 years in comparison to the prior 20 years. This becomes also evident in the final ABI chronology, where the carbon accumulation was on average $39 \%$ higher from 1977 to 1996, compared to the 1957-1976 period (Fig. 5). However, this increase in total
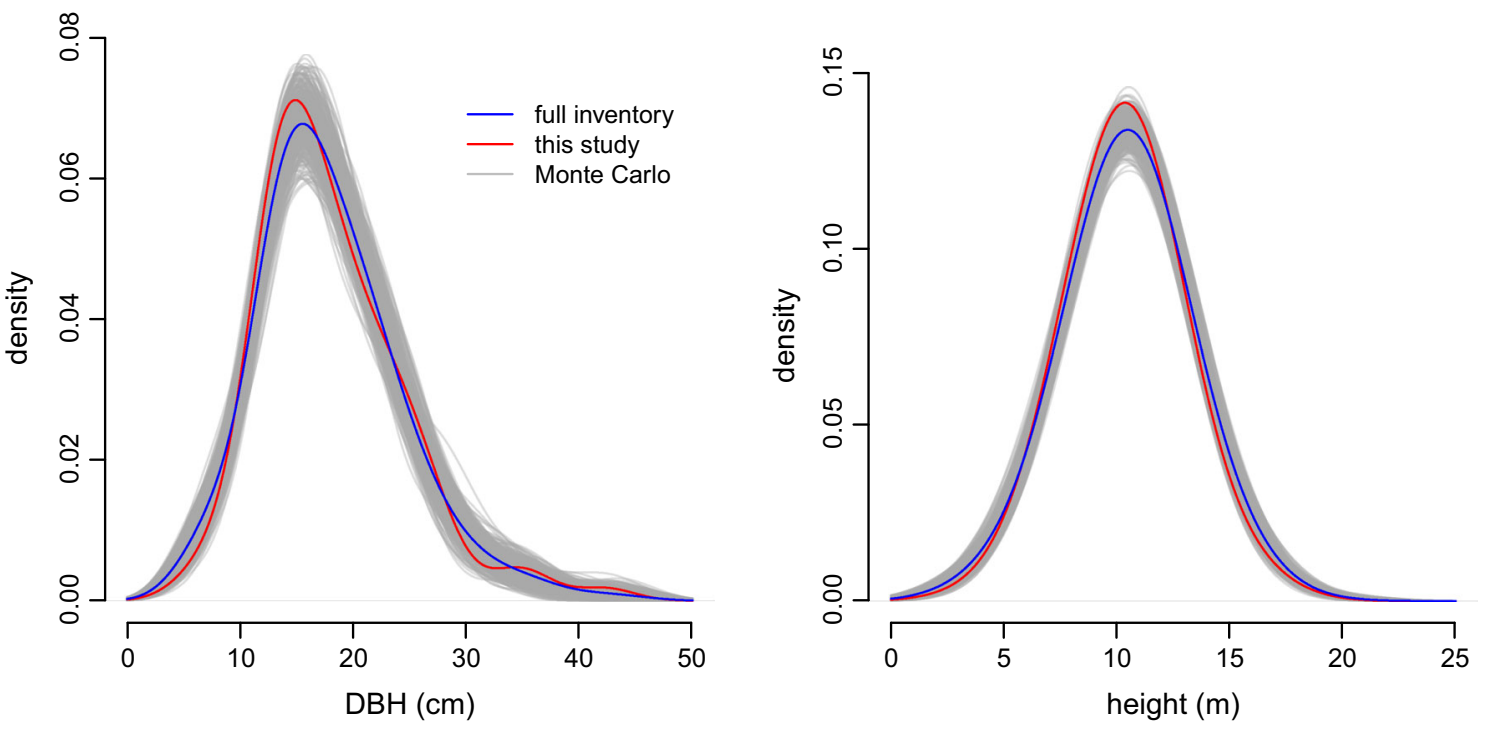

Fig. 3 Density distribution of DBH (left) and height (right) of the 272 sampled trees (red), the full inventory (blue) and 272 Monte Carlo-type chosen trees (500 iterations). DBH and height data are from the 1999 inventory. (Color figure online)

Table 1 Mean (median) and median absolute deviation of DBH and height of sampled subset and total population (based on full inventory 1999) with $p$ value of the Wilcoxon test

\begin{tabular}{llll}
\hline & Subset $(n=272)$ & Whole population $(n=2775)$ & $p$ value \\
\hline DBH $(\mathrm{cm})$ & $18.06(16.87) \pm 5.57$ & $17.96(17.00) \pm 5.62$ & 0.8133 \\
Height $(\mathrm{m})$ & $10.34(10.45) \pm 1.85$ & $10.45(10.50) \pm 2.07$ & 0.4759 \\
\hline
\end{tabular}




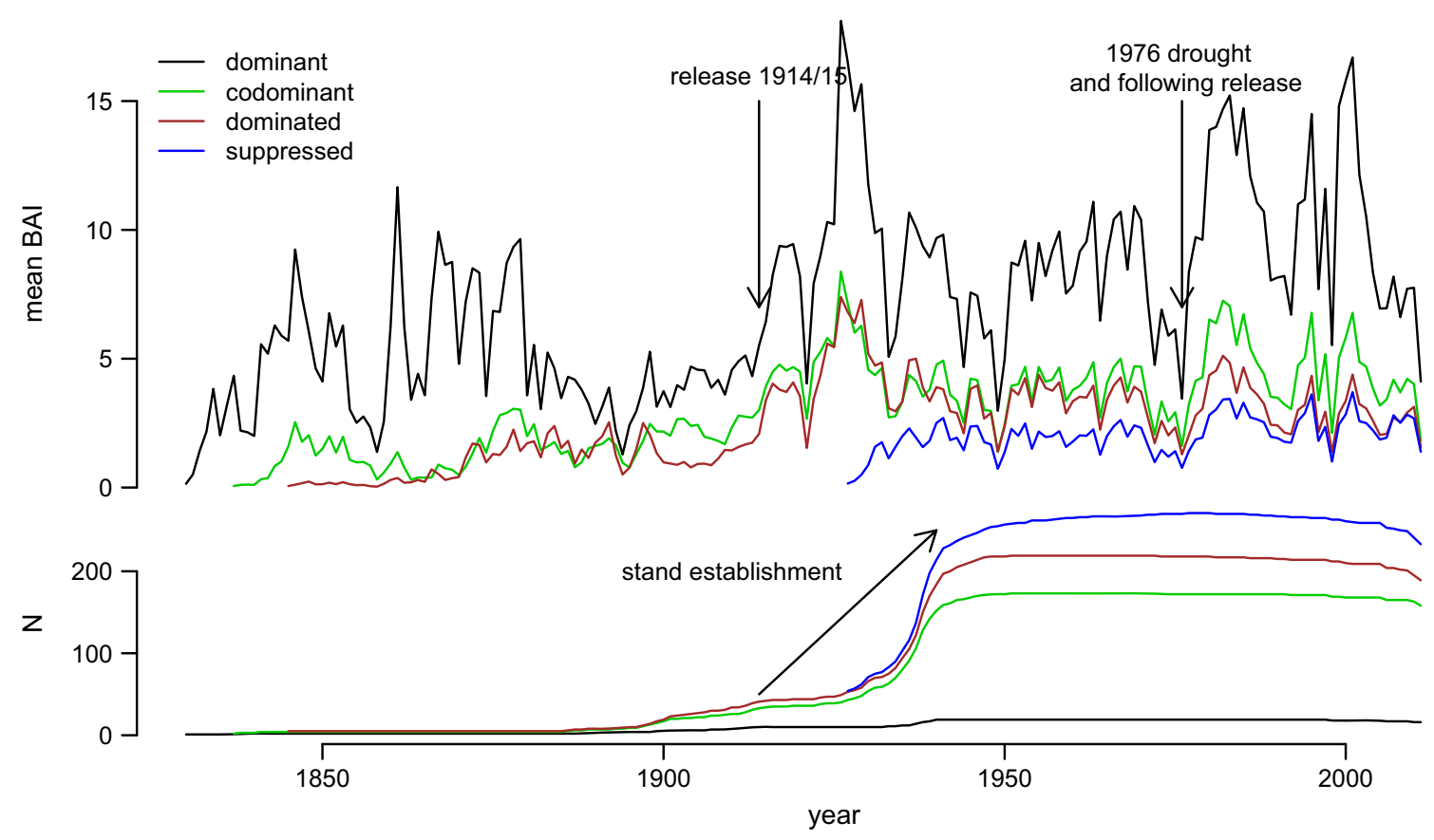

Fig. 4 Mean basal area increment ( $\mathrm{cm}^{2} /$ upper panel) and sample replication (lower panel) of trees belonging to one of the four different social classes defined in the 1999 inventory

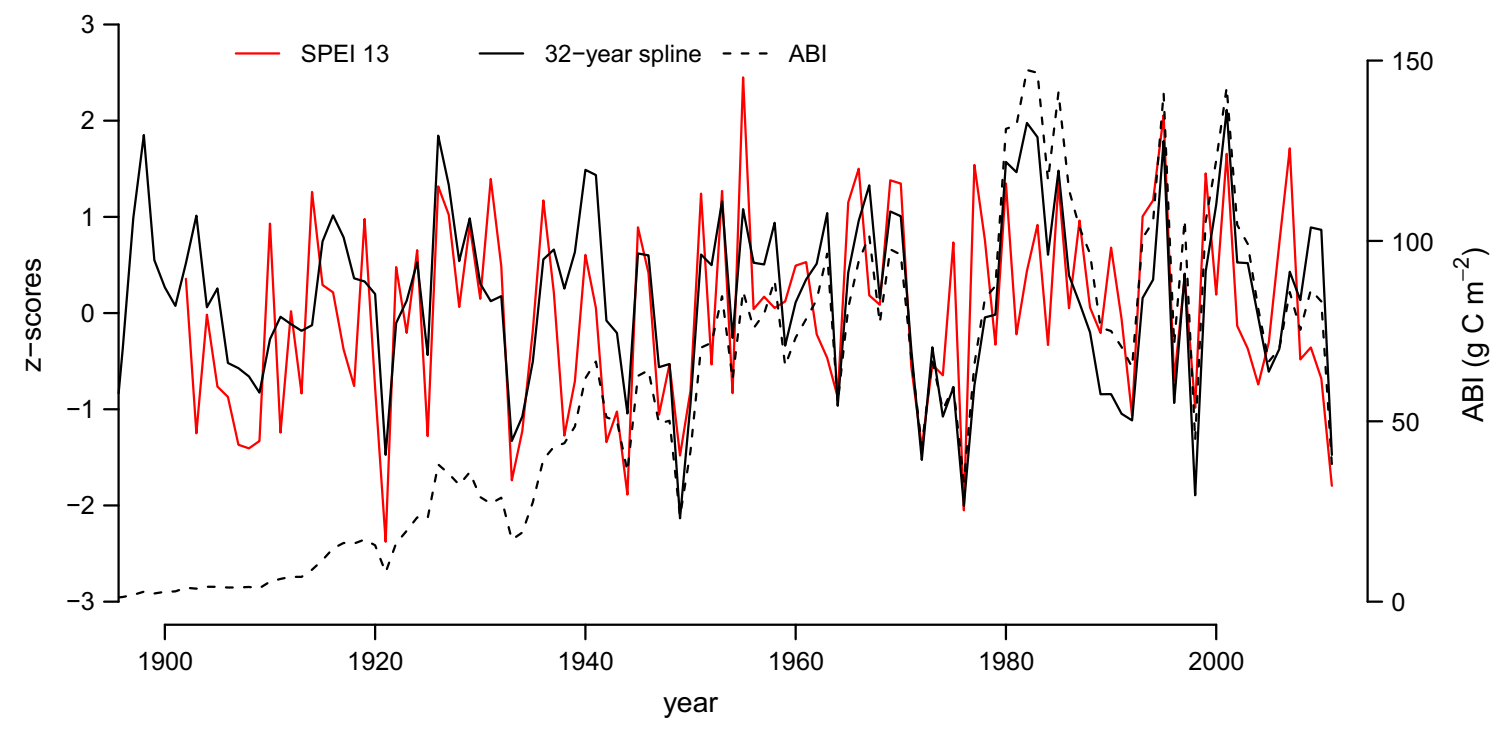

Fig. 5 Normalized SPEI13 $3_{\text {August }}$ time series (red) and 32-year-spline chronology (full black line, left axis) and absolute ABI chronology (dashed black line, right axis). (Color figure online)

stand ABI could be an artifact of missing trees that died around 1977 and were subsequently either removed or decayed beyond recognition.

\section{Comparison with Inventory data}

The mean annual ABI from 1950 to 2011 was $86.6 \pm 27.2 \mathrm{~g} \mathrm{C}$ year $^{-1} \mathrm{~m}^{-2}$, and during the inventory period (1996-2010) the ABI was $89.6 \pm 24.3 \mathrm{~g} \mathrm{C}$ year $^{-1} \mathrm{~m}^{-2}$.
This corresponds to an IAV, calculated as the coefficient of variation, of 31.4 or $27.2 \%$, respectively. Assessment of the individual tree growth derived from the annually resolved tree-ring data compared to the repeated (approximately every 5 years) inventory generally yields very consistent results. Compared to the inventory data the tree-ring data mostly underestimate growth in the first period (1996-1999, median $=85 \pm 30 \%$ ), whereas they tend to slightly overestimate in the second and third inventory period (106 \pm 25 and 

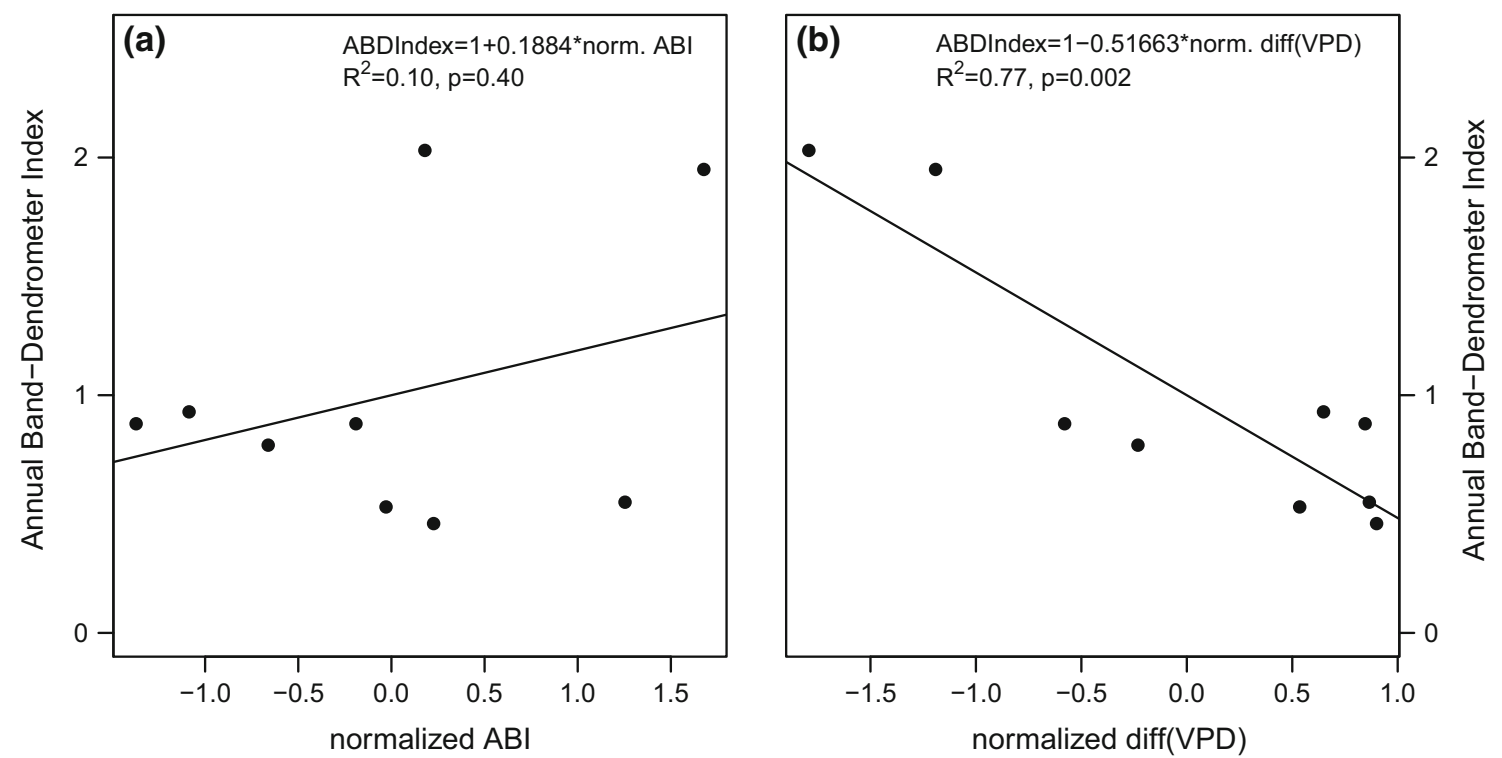

Fig. 6 a Annual band-dendrometer index plotted against normalized ABI values and b normalized year-to-year differences of water vapor pressure deficit on the day of inventory

$110 \pm 31 \%$, respectively). However, the correlation between the annually read circumference bands and the TRWbased increments was low $(r=0.32, p=0.40, N=9$, Fig. 6a). The year-to-year differences of VPD on the day of inventory explained much of the variation in these measurements (Fig. 6b).

\section{Climate growth response}

The main driving factor of intra-annual tree growth was the SPEI13 from previous August to current August

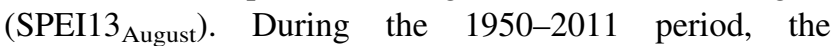
SPEI13 August explains $37 \%$ of the variance $(r=0.61$, $p<0.001$ ) of the 32-year-spline-detrended chronology. Similar values were achieved with the BAI and ABI chronologies ( $r=0.60$ and $r=0.56$, respectively). Correlations between the first differenced series of BAI (ABI) and SPEI were highest from previous September to current August $(r=0.77, p<0.001$ and $r=0.75, p<0.001)$. Correlation with summer only SPEI (May to August) is much weaker $(r=0.34, p<0.01)$. Similar to the SPEI, seasonal precipitation summed from previous September to current August has the highest correlation. Values were: $r=0.62$ with the RCS chronology, $r=0.57$ (32-yearspline-detrended), $r=0.60$ with the BAI, and 0.50 with the ABI chronology. When first differencing was applied, the correlations peaked at $r=0.75$ for ABI and $r=0.76$ for BAI. Temperatures during the growing season had a weak negative influence on tree growth at this long-term monitoring site. The negative correlations were highest from May to June $(r=-0.23$, BAI and RCS; $r=-0.22$, 32-year-spline; $r=-0.16, \mathrm{ABI}$, though not significant $(\mathrm{p}>0.05)$. The correlation coefficients between the splinedetrended chronology and the SPEI13 $3_{\text {August }}$ remained on the same high level over the full 1901-2011 period $(r=0.62)$. The RCS chronology also showed a stable high correlation $(r=0.50)$; however, there was a drop of correlation in the early 40 years of the twentieth century. This is most likely due to a stand dynamics trend retained in the RCS detrending process, where the release effect after 1915 was not removed.

The above correlation exercises demonstrated a high sensitivity of tree growth at this long-term monitoring site to inter-annual hydroclimate variability. However, the response to the SPEI13 ${ }_{\text {August }}$ appears to be nonlinear. The relative growth decrease in the different size classes during negative SPEI years compared to normal years (SPEI 0) was highly significant $(p<0.001)$ and in the same magnitude $(-30 \%$ from SPEI 0 to SPEI -1 and $-66 \%$ from SPEI 0 to SPEI -2; Fig. 7). In contrast, there was only a small benefit to growth during wetter years $(+6 \%$ for SPEI $+1, p<0.05$ for the two intermediate size classes and $+9 \%$ for SPEI $+2, p<0.05$ for all but the smallest size class). A similar nonlinear response to SPEI13 August can be observed in the spline-detrended chronology over the full 1901-2011 period (black diamonds in Fig. S1), with a median ring width index at SPEI -2 of 0.6. In 1976, a well-known drought year in western-central Europe, this pine forest sequestered only $33.2 \mathrm{~g} \mathrm{C} \mathrm{m}^{-2}$, which is $61 \%$ less than the mean annual ABI. Also other pronounced dry years with SPEI -1 or lower caused $\sim 50 \%$ growth reductions such as in $1972(-50.1 \%), 1998(-48.3 \%)$ or $2011(-55.9 \%)$. 


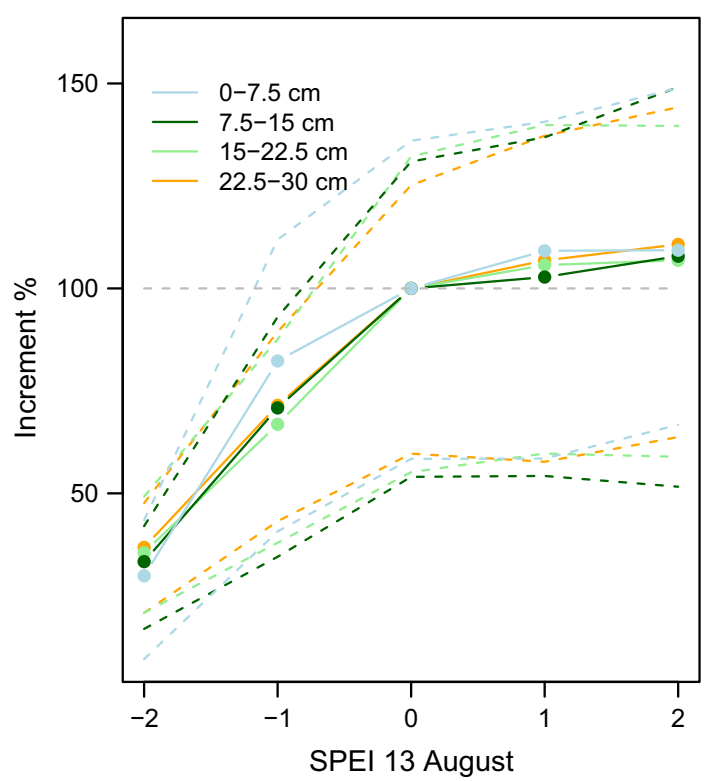

Fig. 7 Median percentage growth change of trees in different size classes during stratified SPEI13 $3_{\text {August }}$ years in relation to normal years (=SPEI 0)

\section{Stand recovery}

During the 2011/2012 snowstorm event, 400 living trees, which comprised $93.2 \mathrm{~m}^{3}$ wood or $16.7 \%$ of the total living wood volume (17.4\% of the number of the trees), were removed from the forest, with the majority immediately killed or heavily damaged by the extreme weather. There is no indication that trees of a certain size or height class were preferentially impacted by the storm (see also Fig. 3). All biometric characteristics (height, DBH and crown transparency) of the broken and thrown trees are not statistically different from the population $(p>0.15)$. No difference could be observed in the growth rate over the last 10 years between the unharmed $\left(4.02 \mathrm{~cm}^{2}\right)$ and the broken trees $\left(3.94 \mathrm{~cm}^{2}, p=0.78\right)$. The thrown trees, however, had a significantly higher growth rate $\left(4.79 \mathrm{~cm}^{2}\right.$, $p=0.004$ ). Assuming the same average growth rate of $0.003 \mathrm{~m}^{3}$ year $^{-1}$ per tree as in the 62 years before, the remaining 1897 living trees would take approximately 16 years, or until 2027, to make up for the loss of this event, i.e., to reach the same stock of living biomass as before the storm damage.

\section{Discussion}

\section{Implications of sampling design on TRW inventory comparisons}

The newly acquired dataset used in this study is highly representative of all stand characteristics (DBH, height, crown transparency, social classes) at this long-term forest ecosystem research site. As has been previously reported by Nehrbass-Ahles et al. (2014), this nearly randomized sampling design and highly replicated dataset is well suited for the investigation of annually resolved absolute trends and growth levels (and the inter-annual variability) of forests. The performed tests using multiple radii from different slope directions in different combinations show the robustness of using the mean of all 4 radii (up-/downhill, slope-parallel) to reflect the true basal area of a tree (i.e., $1.1 \pm 2.7 \%$ overestimation). The mean growth of all 4 radii possibly accounts best for eccentric growth behavior, e.g., when carbon allocation changes around the stem, due to stabilization processes on only one or two sides (Buras and Wilmking 2014). However, we find that the standard approach using two slope-parallel cores is also a reasonable alternative with a $5 \pm 9.7 \%$ underestimation in reconstructing past diameter growth and hence annual biomass increment. Together with the lower-resolution inventory data used to calibrate for the inside/outside bark correction for upscaling purposes, the data yield robust $\mathrm{ABI}$ estimates more than 40 years prior to the setup of this monitoring plot and allow detailed insight into growth dynamics along all size and social classes. We find that comparisons with conservatively detrended chronologies as produced with splines or negative exponential curves or output from dynamic global vegetation models (Girardin et al. 2014), and detailed analyses on the tree level will help evaluating the validity of annually resolved ABI trend estimates and problems related due to the "fading record" problem (Swetnam et al. 1999; Babst et al. 2013a).

Overall we found very good agreement between the tree-ring derived $\mathrm{ABI}$ estimates and those based upon the bi-decadal inventory measurements. But on the other hand, we found a low correlation with the annual band-dendrometer measurements. The inventory-based average growth rate of woody aboveground biomass from 1996 to 2010 was $90.14 \mathrm{~g} \mathrm{C}_{\text {year }}{ }^{-1} \mathrm{~m}^{-2}$, which equals $30-35 \%$ of this site's total NPP (Etzold et al. 2014), is nearly identical to our tree-ring based value of $89.6 \mathrm{~g} \mathrm{C}_{\text {year }}{ }^{-1} \mathrm{~m}^{-2}$ from a subset of the monitoring plot. Based on point-dendrometer measurements, Zweifel et al. (2005) reported a maximum stem shrinkage of up to $1 \mathrm{~mm}$, after 2 weeks without rainfall during summer 2002 in a nearby pine forest. Even after only seven dry days, stem shrinkage can be in the range of $0.2-0.6 \mathrm{~mm}$. Due to these short-term tree waterdeficit fluctuations, care must thus be taken of yearly derived increments from manual circumference bands, as used in Etzold et al. (2014), especially where stem shrinkage in trees with thick bark and phloem, such as $P$. sylvestris or $L$. decidua, can easily surpass annual woody increments. In fact, the annual variation of the manual 
circumference bands at this site can be largely explained by the year-to-year difference in water vapor pressure deficit on the single day the circumference band was read $\left(R^{2}=0.77, p<0.01\right)$. Measurements taken on a wet day following a drier day the year before lead to higher increments and vice versa (Fig. 6b). Even if a bi-decadal inventory were conducted during such a drought period, the derived growth estimates could be negatively affected, especially in forests with low growth rates such as our site with only $0.13 \mathrm{~mm}$ radial increment per year. The linear regression slopes of the radius to DBH conversion from the first two inventories (2.429 and 2.432) are higher than from the third and fourth inventory (2.42 and 2.41). Although these changes are rather small, a negative trend of bark thickness relative to wood increment can be observed over the inventory period 1996-2010. The 1996 inventory was conducted during a dry spell of 9 consecutive dry days in July. Thus, the first inventory-based growth increment (1996-1999) is likely biased toward too high values compared to the tree-ring measurements, which show on average $15 \%$ lower increment for this period. During the second inventory survey, weather conditions were rather moist, which is reflected in very similar tree-ring-based ABI values compared to the inventory. Data from automated dendrometers (Zweifel et al. 2006; King et al. 2013), which continuously record stem radius fluctuations, could give a more precise picture of annual tree growth and internal water status.

The wide geographical coverage of tree-ring chronologies has allowed the establishment of hemispheric networks to assess spatiotemporal variability of forest growth in the context of global change and rising $\mathrm{CO}_{2}$ levels (Gedalof and Berg 2010), climate extremes (Babst et al. 2012) or influence of local climate and the global climate system (Babst et al. 2013b; St. George 2014; St. George and Ault 2014). However, due to the lack of tree biometrics, such as tree height and $\mathrm{DBH}$, the absence of stand related metadata, such as tree positions, stand density, social status, and the plethora of different sampling designs used in the original coring, it is difficult to use most of the existing datasets to quantify the absolute level, inter-annual variability and trends of forest growth. Nehrbass-Ahles et al. (2014) showed that the classic sampling approach, where usually around 20 dominant and undisturbed trees are cored, returns high overestimations of trends and level of the actual population growth signal. They conclude that the smallest bias in relation to the population is obtained by either randomized sampling or by the fixed plot sampling (Babst et al. 2014b), where the amount of growth can be easily attributed to an area $\left(\mathrm{kg} / \mathrm{ha}\right.$ or $\left.\mathrm{g} \mathrm{C} \mathrm{m}^{-2}\right)$ and hence compared with measurements derived from inventories (Metsaranta and Lieffers 2009) or eddy covariance flux measurements (Babst et al. 2013a). If in our study only dominant trees had been cored and inferences drawn therefrom, a resulting $127 \%$ overestimation of stand productivity would have occurred. Such an overestimate is in the range of previously reported biases attributed to the "classic" sampling (Brienen et al. 2012; Nehrbass-Ahles et al. 2014). Interestingly, the relative IAV is constant along social classes, so the classic sampling approach would not bias the climate sensitivity of the $\mathrm{ABI}$ chronology. This has implications for using existing treering datasets into the assessment of annual increments of forest inventory plots and hence carbon balance accounting schemes. If the decadal increment (or the increment during any other interval) is known, it should be possible to scale the mean BAI/ABI chronologies to the growth level of the inventory period mean. A minimum requirement for those series would, however, still be the presence of pith offset estimates in combination with distance to pith estimates, DBH and height estimates derived from DBH (Babst et al. 2014b).

\section{Climate impacts on annual forest growth variability}

The high sensitivity of the pines in Lens to hydrological conditions from previous year August to current August is in line with other studies of low-elevation $P$. sylvestris forests in the Valais (Rigling et al. 2001; Bigler et al. 2006; Eilmann et al. 2006). The negative effect of drought over such a long integrated period can have multiple implications for growth reduction: Drought during the previous fall and current spring, and heat during the growing season can reduce tree growth (Rigling et al. 2002; Fritts 1976). Spring drought also affects the elongation and development of young needles (Grill et al. 2004), whereas storage reduction due to late summer drought reduces shoot length in the following year (Löf and Welander 2000). Another indirect negative effect on growth is the reduction of photosynthetic capacity due to needle loss following drought stress (Pouttu and Dobbertin 2000; Solberg 2004). Although the poor representation of trees with a high crown transparency did not permit a rigorous statistical assessment, we found increasing crown transparency was associated with lower tree growth rates. The slope of this relationship is the same as found by Dobbertin (2005) in the earliest 3 years of crown transparency measurements at the study site (1996-1999) and also supports conclusions on crown transparency-growth performance at different sites (Solberg 1999; Eilmann et al. 2013).

Pearson correlations between tree growth and SPEI or precipitation yielded highly significant relationships (Fig. 5). However, these methods cannot be used to address nonlinear responses as found herein. In this water-limited ecosystem, the response of growth to precipitation appears to be asymptotic: Decreased responses are observed toward 
wetter conditions, whereas below normal precipitation has disproportionally high impacts on growth (Fig. 7). Similar curvilinear responses can be observed at several sites across Europe with a high correlation $(r>0.5)$ to SPEI13 August (Fig. S1). Saturation effects were also shown by Gea-Izquierdo et al. (2011) across different Quercus ilex stands in Spain, where the trees did not benefit from additional precipitation if temperatures were not warm enough. This might also explain the negative relationship between tree growth and summer temperatures $(r=-0.23)$, which are negatively correlated to precipitation values $(r=-0.41$ and -0.54 in June and July, respectively).

To improve carbon uptake estimations and projections, it is desirable to obtain ecologically more meaningful response trajectories through detection of threshold or saturation limits, e.g., through the application of artificial neural networks as applied by Carrer and Urbinati (2001) or Woodhouse (1999). Alternatively, a high replication of trees of all size classes is necessary to be able to stratify the tree-ring data and investigate the growth reduction or enhancement during specific climate conditions. This method of size class isolation has recently been shown to be a reliable method to detect growth trends in tree-ring studies (Peters et al. 2014). The negative impact of severe droughts on carbon uptake at the study site of up to $60 \%$ growth decrease ( $\sim 2 \mathrm{SD}$, $<38 \mathrm{~g} \mathrm{C} \mathrm{m}^{-2}$ year $^{-1}$ ) is in line with the $2 \mathrm{SD}$ departure of satellite-based plant productivity estimates reported by Bastos et al. (2014) for the extreme summers of 2003 and 2010. Interestingly, the extreme summer of 2003 did not have a direct impact on ABI on our site. Although temperatures were well above average, winter and summer precipitation values (with the exception of a dry spring) were near normal. This resulted in an SPEI13 $3_{\text {August }}$ of only -0.36 . On the other hand, growth enhancements of more than $55 \%$ ( $>140 \mathrm{~g} \mathrm{C} \mathrm{m}^{-2}$ year $^{-1}$ ) can be observed during very favorable conditions such as for the years 1982, 1983, 1985, 1995 and 2001. The latter three of which were exceptionally moist $\left(\right.$ SPEI13 $3_{\text {August }}>1.35$ ). The magnitude of the treering-derived growth reduction may be slightly overestimated, if trees tend to reduce stem growth at breast height more than in the upper parts of the tree under difficult growing conditions (Bouriaud et al. 2005; van der MaatenTheunissen and Bouriaud 2012). During summer, assimilates that are produced in the leaves are largely directed to the lower stem and roots (Gower et al. 1995), but under unfavorable conditions those assimilates will be first used for respiration and relatively small amounts may be left for diameter growth (Fritts 1976). However, Kerhoulas and Kane (2012) found in a dry Ponderosa pine forest increasing climate sensitivity to summer drought toward the crown. This would suggest hydraulic limitations rather than carbon allocation deficits driving tree growth along the stem, and hence no exaggerated growth decrease in breast height during drought. Further studies of growth variability along the stem, for multiple tree species, and in diverse ecological and climatic conditions will be required to understand the representativity of tree-ring measurements in deriving full tree growth.

\section{Impacts of disturbances on recovery and forest carbon balance}

Luyssaert et al. (2008) showed that variations in carbon balance among forest sites are not resulting from climatic differences, but rather from factors such as forest age, management, and disturbance history. Similarly Michaletz et al. (2014) found that standing biomass and stand age are the best predictors for mean annual level of NPP. However, the large inter-annual variability of tree growth at this study's site $(\sim 30 \%)$ reflects the underlying influence of climate parameters (in our case moisture conditions from previous August to current August, SPEI13 ${ }_{\text {Aug }}, r=0.56$, first differenced: $r=0.75$ ) on physiological processes including photosynthesis and respiration. Here lies the strength of tree-ring measurements, especially on sites where site-specific disturbance events can mask climategrowth relationships on a lower resolved timescale (Etzold et al. 2014). Many studies report only on the carbon dynamics after stand replacing events from huge storms, forest fires, or clear cuts (Magnani et al. 2007; Seedre et al. 2011). This is partly due to the difficulty in relating latesuccessional biomass development to stand age, especially following moderate-to-high frequency but lower severity disturbances, without tree-ring data (Keeton et al. 2011). Dendroecological methods have proven to be a useful tool for the retrospective study of disturbance dynamics (Pederson et al. 2014, Svoboda et al. 2014, Trotsiuk et al. 2014). Quite recently tree-ring methods were even applied to relate current biomass accumulation rates of moderately disturbed old-growth spruce forest stands to the timing and severity of main disturbance events that occurred decades to centuries prior (Trotsiuk et al. unpublished).

The sudden increase in ABI in 1977 (Fig. 5) could be attributed to a light thinning event. Whether this is due to relaxation of competition after management or natural mortality, we can only speculate, as no detailed data are available from that time. Bigler et al. (2006) reported a high mortality risk between 1972 and 1976 at this site and hence a high probability that some trees in this stand died during or after this dry period. It is thus likely that the high growth rates at this site after 1976 are due to a relaxation of competition in combination with favorable hydrological conditions following those dry years. For this reason, some trees might be missing in the present record. We estimate this should not affect the slope too dramatically after 1950; 
however, care must be taken about the interpretation of the actual ABI level and trends prior 1977.

The trees still remaining in the stand following 2011/2012 snowfall event now have enhanced light and water availability. Thus, one could expect that these survivors will make up the carbon loss faster than the 16 years that would be required assuming growth rates typical for the past decade. An increase in water availability positively affects stomatal conductance (Larcher 2003), resulting in a higher carbon uptake through photosynthesis, and finally to an increased primary production (Wu et al. 2013). A 9-14\% increase in growth (though not significant at $p<0.05$ ) of trees remaining following a light thinning (14\% of BA removed) of a pine forest was reported by Giuggiola et al. (2013). In contrast to their study, where the light thinning was performed from below (i.e., no dominant trees were removed), the loss of the storm event in the present study represents all size and social classes. Growth increases could thus likely be greater than $10 \%$, which would shorten the recovery time span. Furthermore, irrigation experiments showed a significant increase in needle and shoot length under elevated water availability (Dobbertin et al. 2010; Feichtinger et al. 2014), a prolongation of the growing period, and a decrease in crown transparency, all of which leads again to an increase in growth (Eilmann et al. 2011, 2013). However, future climate change scenarios predict a $1-1.5^{\circ} \mathrm{C}$ warming in the Alps by 2035 together with decreased summer precipitation and slightly increased winter precipitation (CH2011 2011). Also the severity and frequency of dry spells are expected to increase (Fischer et al. 2014). The combination of decreasing rainfall, especially in summer, and higher temperatures will result in lower soil water content and may lead to a reduction in cambial activity (Schweingruber 1993; Zweifel et al. 2006; Eilmann et al. 2011). This increased climatic stress may counteract the growth benefits due to decreased light competition and increased water availability. Future inventories and crown transparency measurements, along with other studies (e.g., using TRW and stable isotopes), will show how this storm impacted trees neighboring the damage zones and altered their growth behavior (e.g., growth rate, climate response and physiological adjustments) compared to trees that remained in intact portions of the stand. These investigations will ultimately be able to place the post disturbance effects into the context of growth data of the past $>60$ years acquired in this study.

\section{Conclusions}

Well-replicated tree-ring datasets, preferably collected in a randomized fashion, with trees across all size and age classes can shed valuable insight into the annual carbon uptake variability of forests. Stratifying the increment data according to size classes (or age or social classes) in each year can help understanding if the size-growth relationship remained stable over time, and if trends in the ABI chronology are related to sampling biases, management interventions, or climatic trends. In combination with inventory data, tree-ring data can help improve the temporal resolution of carbon uptake and forest growth trajectories (as suggested in Babst et al. $2014 \mathrm{~b}$ ) and allow the quantification of ABI IAV and the reduction in productivity and vulnerability of forest ecosystems from extreme climate events. In this study, we showed that even small scale, locally restricted disturbances have a considerable impact on the possible carbon uptake, as roughly $10 \%$ of the living biomass was killed, and the subsequent total carbon accumulation rate of the remaining trees will likely be reduced by $\sim 10 \%$ in the initial years following the snow breakage (as the damaged trees resemble the overall population structure). As this disturbance happened on a ICP Level 2 monitoring plot, with a plethora of sub-daily, monthly to bi-decadal measurements existing since 1996 (including meteorological data, soil moisture, litter fall and soil-atmosphere gas exchange measurements), there will be further great opportunities to study the consequences of this lower severity disturbance on carbon cycle dynamics in the coming years to decades.

Acknowledgments The authors like to thank Diana Zoglauer and Severin Meier for the tree-ring measurements, Sèrge Borer, Dieter Trummer, Janina Müller, and Dani Nievergelt for their help in the field, Flurin Sutter for answering the numerous questions concerning the inventory data and Volodymyr Trotsiuk for discussion. SK and DF are supported by SNF iTREE Sinergia Project 136295.

\section{References}

Allen CD, Macalady AK, Chenchouni $\mathrm{H}$ et al (2010) A global overview of drought and heat-induced tree mortality reveals emerging climate change risks for forests. For Ecol Manage 259:660-684. doi:10.1016/j.foreco.2009.09.001

Babst F, Carrer M, Poulter B et al (2012) 500 years of regional forest growth variability and links to climatic extreme events in Europe. Environ Res Lett 7:045705. doi:10.1088/1748-9326/7/4/ 045705

Babst F, Bouriaud O, Papale D et al (2013a) Above-ground woody carbon sequestration measured from tree rings is coherent with net ecosystem productivity at five eddy-covariance sites. New Phytol 201:1289-1303. doi:10.1111/nph.12589

Babst F, Poulter B, Trouet V et al (2013b) Site- and species-specific responses of forest growth to climate across the European continent. Glob Ecol Biogeogr 22:706-717. doi:10.1111/geb. 12023

Babst F, Alexander MR, Szejner P et al (2014a) A tree-ring perspective on the terrestrial carbon cycle. Oecologia. doi:10. 1007/s00442-014-3031-6 
Babst F, Bouriaud O, Alexander R et al (2014b) Towards consistent measurements of carbon accumulation: a multi-site assessment of biomass and basal area increment across Europe. Dendrochronologia 32:153-161. doi:10.1016/j.dendro.2014.01.002

Bastos A, Gouveia CM, Trigo RM, Running SW (2014) Analysing the spatio-temporal impacts of the 2003 and 2010 extreme heatwaves on plant productivity in Europe. Biogeosciences 11:3421-3435. doi:10.5194/bg-11-3421-2014

Beer C, Reichstein M, Tomelleri E et al (2010) Terrestrial gross carbon dioxide uptake: global distribution and covariation with climate. Science 329:834-838. doi:10.1126/science.1184984

Bigler C, Rigling A (2013) Precision and accuracy of tree-ring-based death dates of mountain pines in the Swiss National Park. Trees 27:1703-1712. doi:10.1007/s00468-013-0917-6

Bigler C, Bräker OU, Bugmann H et al (2006) Drought as an inciting mortality factor in Scots pine stands of the Valais, Switzerland. Ecosystems 9:330-343. doi:10.1007/s10021-005-0126-2

Bouriaud O, Bréda N, Dupouey J-L, Granier A (2005) Is ring width a reliable proxy for stem-biomass increment? A case study in European beech. Can J For Res 35:2920-2933. doi:10.1139/x05202

Brändli UB (2010) Schweizerisches Landesforstinventar. Ergebnisse der dritten Erhebung 2004-2006. Swiss Federal Institute for Forest, Snow and Landscape Research (WSL), Birmensdorf, Switzerland. Swiss Federal Office for Environment, Bern, Switzerland, pp 1-312

Brang P (1997) Aufnahmeanleitungen aller Forschungsprojekte auf Flächen der Langfristigen Waldökosystem-Forschung (LWF). Swiss Federal Institute for Forest, Snow and Landscape Research (WSL), Birmensdorf

Brassel P, Lischke H (2001) Swiss national forest inventory: methods and models of the second assessment. WSL Swiss Federal Research Institute, Birmensdorf

Brienen RJW, Gloor E, Zuidema PA (2012) Detecting evidence for $\mathrm{CO} 2$ fertilization from tree ring studies: The potential role of sampling biases. Global Biogeochem Cycles 26:GB1025. doi:10. 1029/2011GB004143

Briffa KR, Melvin TM (2011) A closer look at regional curve standardization of tree-ring records: justification of the need, a warning of some pitfalls, and suggested improvements in its application. In: Hughes MK, Swetnam TW, Diaz HF (eds) Dendroclimatology. Springer, Netherlands, pp 113-145

Buras A, Wilmking M (2014) Straight lines or eccentric eggs? A comparison of radial and spatial ring width measurements and its implications for climate transfer functions. Dendrochronologia 32:313-326. doi:10.1016/j.dendro.2014.07.002

Canadell JG, Raupach MR (2008) Managing forests for climate change mitigation. Science 320:1456-1457. doi:10.1126/ science. 1155458

Carrer M, Urbinati C (2001) Assessing climate-growth relationships: a comparative study between linear and non-linear methods. Dendrochronologia 19:57-65

CH2011 (2011) Swiss Climate Change Scenarios CH2011, published by C2SM, MeteoSwiss, ETH, NCCR Climate, and OcCC, Zurich, Switzerland, $88 \mathrm{pp}$

Ciais P, Reichstein M, Viovy N et al (2005) Europe-wide reduction in primary productivity caused by the heat and drought in 2003 . Nature 437:529-533. doi:10.1038/nature03972

Cook ER, Peters K (1981) The smoothing spline: A new approach to standardizing forest interior tree-ring width series for dendroclimatic studies. Tree Ring Bull 41:45-53

Dobbertin M (2005) Tree growth as indicator of tree vitality and of tree reaction to environmental stress: a review. Eur J For Res 124:319-333. doi:10.1007/s10342-005-0085-3

Dobbertin M, Eilmann B, Bleuler P et al (2010) Effect of irrigation on needle morphology, shoot and stem growth in a drought-exposed
Pinus sylvestris forest. Tree Physiol 30:346-360. doi:10.1093/ treephys/tpp123

Eilmann B, Weber P, Rigling A, Eckstein D (2006) Growth reactions of Pinus sylvestris L. and Quercus pubescens Willd. to drought years at a xeric site in Valais. Switzerland. Dendrochronologia 23:121-132. doi:10.1016/j.dendro.2005.10.002

Eilmann B, Zweifel R, Buchmann N et al (2011) Drought alters timing, quantity, and quality of wood formation in Scots pine. J Exp Bot 62:2763-2771. doi:10.1093/jxb/erq443

Eilmann B, Dobbertin M, Rigling A (2013) Growth response of Scots pine with different crown transparency status to drought release. Ann For Sci 70:685-693. doi:10.1007/s13595-013-0310-z

Esper J, Büntgen U, Frank DC et al (2007) 1200 years of regular outbreaks in alpine insects. Proc R Soc B 274:671-679. doi:10. 1098/rspb.2006.0191

Esper J, Düthorn E, Krusic PJ et al (2014) Northern European summer temperature variations over the Common Era from integrated tree-ring density records. J Quat Sci 29:487-494. doi:10.1002/ jqs. 2726

Etzold S, Waldner P, Thimonier A et al (2014) Tree growth in Swiss forests between 1995 and 2010 in relation to climate and stand conditions: recent disturbances matter. For Ecol Manage 311:41-55. doi:10.1016/j.foreco.2013.05.040

Feichtinger LM, Eilmann B, Buchmann N, Rigling A (2014) Growth adjustments of conifers to drought and to century-long irrigation. For Ecol Manage 334:96-105. doi:10.1016/j.foreco.2014.08.008

Fischer AM, Keller DE, Liniger MA et al (2014) Projected changes in precipitation intensity and frequency in Switzerland: a multimodel perspective. Int J Climatol. doi:10.1002/joc.4162

Frank D, Esper J, Cook ER (2006) On variance adjustments in treering chronology development. Tree Rings Archaeol Climatol Ecol 4:56-66

Frank DC, Esper J, Raible CC et al (2010) Ensemble reconstruction constraints on the global carbon cycle sensitivity to climate. Nature 463:527-530. doi:10.1038/nature08769

Friedlingstein P, Houghton RA, Marland G et al (2010) Update on $\mathrm{CO}_{2}$ emissions. Nat Geosci 3:811-812. doi:10.1038/ngeo1022

Fritts H (1976) Tree rings and climate. London

Gardiner B, Blennow K, Carnus JM, et al (2010) Destructive storms in European forests: past and forthcoming impacts. $138 \mathrm{pp}$

Gärtner H, Esper J, Treydte K (2004) Geomorphologie und Jahrringe-Feldmethoden in der Dendrogeomorphologie I Geomorphology and tree rings-field methods in dendrogeomorphology. Schweizerische Zeitschrift fur Forstwesen 155:198-207. doi:10.3188/szf.2004.0198

Gea-Izquierdo G, Cherubini P, Cañellas I (2011) Tree-rings reflect the impact of climate change on Quercus ilex L. along a temperature gradient in Spain over the last 100years. For Ecol Manage 262:1807-1816. doi:10.1016/j.foreco.2011.07.025

Gedalof Z, Berg AA (2010) Tree ring evidence for limited direct $\mathrm{CO}_{2}$ fertilization of forests over the 20th century. Global Biogeochem Cycles 24:GB3027. doi:10.1029/2009GB003699

Girardin MP, Guo XJ, De Jong R et al (2014) Unusual forest growth decline in boreal North America covaries with the retreat of Arctic sea ice. Glob Change Biol 20:851-866. doi:10.1111/gcb.12400

Giuggiola A, Bugmann H, Zingg A et al (2013) Reduction of stand density increases drought resistance in xeric Scots pine forests. For Ecol Manage 310:827-835. doi:10.1016/j.foreco.2013.09. 030

Gower ST, Isebrands JG, Sheriff DW (1995) Carbon allocation and accumulation in conifers. In: Smith WK, Hinckley TM (eds) Resource physiology of conifers: acquisition, allocation, and utilization. Academic Press, San Diego, pp 217-254

Grill D, Tausz M, Pöllinger U et al (2004) Effects of drought on needle anatomy of Pinus canariensis. Flora Morphol Distrib Funct Ecol Plants 199:85-89. doi:10.1078/0367-2530-00137 
Hanewinkel M, Frutig F, Lemm R (2013) Economic performance of uneven-aged forests analysed with annuities. Forestry. doi:10. 1093/forestry/cpt043

Harris I, Jones Pd, Osborn Tj, Lister Dh (2014) Updated high-resolution grids of monthly climatic observations - the CRU TS3.10 Dataset. Int J Climatol 34:623-642. doi:10.1002/joc.3711

Holmes RL (1983) Computer-assisted quality control in tree-ring dating and measurement. Tree Ring Bull 43:69-78

Hug C, Dobbertin M, Nussbaumer C, Stettler Y (2011) Aufnahmeanleitung für die Brusthöhenumfang- und Höheninventur auf den Flächen der Langfristige Waldökosystemforschung (LWF) Swiss Federal Institute für Forest, Snow and Landscape Research (WSL). Birmensdorf, Switzerland

Jolly WM, Dobbertin M, Zimmermann NE, Reichstein M (2005) Divergent vegetation growth responses to the 2003 heat wave in the Swiss Alps. Geophys Res Lett 32:L18409. doi:10.1029/ 2005GL023252

Joosten R, Schumacher J, Wirth C, Schulte A (2004) Evaluating tree carbon predictions for beech (Fagus sylvatica L.) in western Germany. For Ecol Manage 189:87-96. doi:10.1016/j.foreco. 2003.07.037

Kaufmann E (2001) Estimating standing timber, growth and cut. In: Brassel P, Lischke H (eds) Swiss National Forest Inventory: methods and models of the second assessment. Swiss Federal Institute for Forest, Snow and Landscape Research (WSL), Birmensdorf, pp 162-196

Keeton WS, Whitman AA, McGee GC, Goodale CL (2011) Latesuccessional biomass development in northern hardwood-conifer forests of the northeastern United States. For Sci 57:489-505

Kerhoulas LP, Kane JM (2012) Sensitivity of ring growth and carbon allocation to climatic variation vary within ponderosa pine trees. Tree Physiol 32:14-23. doi:10.1093/treephys/tpr112

King G, Fonti P, Nievergelt D et al (2013) Climatic drivers of hourly to yearly tree radius variations along a $6 \mathrm{C}$ natural warming gradient. Agric For Meteorol 168:36-46. doi:10.1016/j.agrfor met.2012.08.002

Kurz WA, Dymond CC, Stinson G et al (2008) Mountain pine beetle and forest carbon feedback to climate change. Nature 452:987-990. doi:10.1038/nature06777

Larcher W (2003) Physiological plant ecology: ecophysiology and stress physiology of functional groups. Springer, Berlin

Le Page Y, Hurtt G, Thomson AM et al (2013) Sensitivity of climate mitigation strategies to natural disturbances. Environ Res Lett 8:015018. doi:10.1088/1748-9326/8/1/015018

Le Quéré C, Moriarty R, Andrew RM et al (2015) Global carbon budget 2014. Earth System Sci Data 7:47-85. doi:10.5194/essd7-47-2015

Lindroth A, Lagergren F, Grelle A et al (2009) Storms can cause Europe-wide reduction in forest carbon sink. Glob Change Biol 15:346-355. doi:10.1111/j.1365-2486.2008.01719.x

Löf M, Welander NT (2000) Carry-over effects on growth and transpiration in Fagus sylvatica seedlings after drought at various stages of development. Can J For Res 30:468-475. doi:10.1139/ x $99-232$

Luyssaert S, Schulze E-D, Börner A et al (2008) Old-growth forests as global carbon sinks. Nature 455:213-215. doi:10.1038/ nature 07276

Magnani F, Mencuccini M, Borghetti M et al (2007) The human footprint in the carbon cycle of temperate and boreal forests. Nature 447:849-851. doi:10.1038/nature05847

Manusch C, Bugmann H, Wolf A (2014) The impact of climate change and its uncertainty on carbon storage in Switzerland. Reg Environ Change. doi:10.1007/s10113-014-0586-z

Martin-Benito D, Pederson N, McDonald M et al (2014) Dendrochronological dating of the world trade center ship, Lower
Manhattan, New York City. Tree Ring Res 70:65-77. doi:10. 3959/1536-1098-70.2.65

Metsaranta JM, Lieffers VJ (2009) Using dendrochronology to obtain annual data for modelling stand development: a supplement to permanent sample plots. Forestry 82:163-173. doi:10.1093/ forestry/cpn051

Michaletz ST, Cheng D, Kerkhoff AJ, Enquist BJ (2014) Convergence of terrestrial plant production across global climate gradients. Nature. doi:10.1038/nature13470

Nabuurs G-J, Lindner M, Verkerk PJ et al (2013) First signs of carbon sink saturation in European forest biomass. Nat Clim Change 3:792-796. doi:10.1038/nclimate1853

Nehrbass-Ahles C, Babst F, Klesse S et al (2014) The influence of sampling design on tree-ring-based quantification of forest growth. Glob Change Biol 20:2867-2885. doi:10.1111/gcb.12599

Nemani RR, Keeling CD, Hashimoto H et al (2003) Climate-driven increases in global terrestrial net primary production from 1982 to 1999 . Science 300:1560-1563. doi:10.1126/science. 1082750

Osborn TJ, Briffa KR, Jones PD (1997) Adjusting variance for sample size in tree-ring chronologies and other regional mean timeseries. Dendrochronologia 15:89-99

Pan Y, Birdsey RA, Fang J et al (2011) A large and persistent carbon sink in the world's forests. Science 333:988-993. doi:10.1126/ science. 1201609

Pederson N, Dyer JM, McEwan RW et al (2014) The legacy of episodic climatic events in shaping temperate, broadleaf forests. Ecol Monogr 84:599-620. doi:10.1890/13-1025.1

Peters RL, Groenendijk P, Vlam M, Zuidema PA (2014) Detecting long-term growth trends using tree rings: a critical evaluation of methods. Glob Change Biol. doi:10.1111/gcb.12826

Poulter B, Frank D, Ciais P et al (2014) Contribution of semi-arid ecosystems to interannual variability of the global carbon cycle. Nature 509:600-603. doi:10.1038/nature13376

Pouttu A, Dobbertin M (2000) Needle-retention and density patterns in Pinus sylvestris in the Rhone Valley of Switzerland: comparing results of the needle-trace method with visual defoliation assessments. Can J For Res 30:1973-1982. doi:10. 1139/x00-127

Pretzsch H, Biber P, Schütze G et al (2014) Forest stand growth dynamics in Central Europe have accelerated since 1870. Nat Commun 5:4967. doi:10.1038/ncomms5967

Reichstein M, Bahn M, Ciais P et al (2013) Climate extremes and the carbon cycle. Nature 500:287-295. doi:10.1038/nature 12350

Rigling A, Waldner PO, Forster T et al (2001) Ecological interpretation of tree-ring width and intraannual density fluctuations in Pinus sylvestris on dry sites in the central Alps and Siberia. Can J For Res 31:18-31. doi:10.1139/cjfr-31-1-18

Rigling A, Bräker O, Schneiter G, Schweingruber F (2002) Intraannual tree-ring parameters indicating differences in drought stress of Pinus sylvestris forests within the Erico-Pinion in the Valais (Switzerland). Plant Ecol 163:105-121. doi:10.1023/A: 1020355407821

Schweingruber FH (1993) Trees and wood in dendrochronology: morphological, anatomical, and tree-ring analytical characteristics of trees frequently used in dendrochronology. Springer, Berlin

Seedre M, Shrestha BM, Chen HYH et al (2011) Carbon dynamics of North American boreal forest after stand replacing wildfire and clearcut logging. J For Res 16:168-183. doi:10.1007/s10310011-0264-7

Seidl R, Schelhaas M-J, Rammer W, Verkerk PJ (2014) Increasing forest disturbances in Europe and their impact on carbon storage. Nat Clim Change 4:806-810. doi:10.1038/nclimate2318

Solberg S (1999) Crown condition and growth relationships within stands of picea abies. Scand J For Res 14:320-327. doi:10.1080/ 02827589950152638 
Solberg S (2004) Summer drought: a driver for crown condition and mortality of Norway spruce in Norway. For Pathol 34:93-104. doi:10.1111/j.1439-0329.2004.00351.x

St. George S (2014) An overview of tree-ring width records across the Northern Hemisphere. Quat Sci Rev 95:132-150. doi:10.1016/j. quascirev.2014.04.029

St. George S, Ault TR (2014) The imprint of climate within Northern Hemisphere trees. Quat Sci Rev 89:1-4. doi:10.1016/j.quascirev. 2014.01.007

Stoffel M, Corona C (2014) Dendroecological dating of geomorphic disturbance in trees. Tree Ring Res 70:3-20. doi:10.3959/15361098-70.1.3

Svoboda M, Janda P, Bače R et al (2014) Landscape-level variability in historical disturbance in primary Picea abies mountain forests of the Eastern Carpathians, Romania. J Veg Sci 25:386-401. doi:10.1111/jvs.12109

Swetnam TW, Allen CD, Betancourt JL (1999) Applied historical ecology: using the past to manage for the future. Ecol Appl 9:1189-1206

Thimonier A, Kull P, Keller W et al (2011) Ground vegetation monitoring in Swiss forests: comparison of survey methods and implications for trend assessments. Environ Monit Assess 174:47-63. doi:10.1007/s10661-010-1759-y

Trotsiuk V, Svoboda M, Janda P et al (2014) A mixed severity disturbance regime in the primary Picea abies (L.) Karst. forests of the Ukrainian Carpathians. For Ecol Manage 334:144-153. doi:10.1016/j.foreco.2014.09.005

Trotsiuk V, Svoboda M, Weber P, Klesse S, Pederson N, Janda P, Martin-Benito D, Mikolas M, Seedre M, Bace R, Frank D (in preparation) The role of disturbances on the individual tree and stand living above ground biomass stocks and accumulation in the primary montane Picea abies (L.) Karst. Forest

Van der Maaten-Theunissen M, Bouriaud O (2012) Climate-growth relationships at different stem heights in silver fir and Norway spruce. Can J For Res 42:958-969. doi:10.1139/x2012-046

Vicente-Serrano SM, Beguería S, López-Moreno JI (2010) A multiscalar drought index sensitive to global warming: the standardized precipitation evapotranspiration index. J Clim 23:1696-1718. doi:10.1175/2009JCLI2909.1

Weber P, Bugmann H, Rigling A (2007) Radial growth responses to drought of Pinus sylvestris and Quercus pubescens in an innerAlpine dry valley. J Veg Sci 18:777-792. doi:10.1111/j.16541103.2007.tb02594.x

Wilmking M, Hallinger M, Van Bogaert R et al (2012) Continuously missing outer rings in woody plants at their distributional margins. Dendrochronologia 30:213-222. doi:10.1016/j.dendro. 2011.10.001

Woodhouse CA (1999) Artificial neural networks and dendroclimatic reconstructions: an example from the Front Range, Colorado, USA. The Holocene 9:521-529

Wu C, Chen JM, Black TA et al (2013) Interannual variability of net ecosystem productivity in forests is explained by carbon flux phenology in autumn. Glob Ecol Biogeogr 22:994-1006. doi:10. 1111/geb.12044

Zianis D, Seura SM, Metsäntutkimuslaitos (2005) Biomass and stem volume equations for tree species in Europe. Finnish Society of Forest Science, Finnish Forest Research Institute, Helsinki, Finland

Zingg A (1996) Diameter and basal area increment in permanent growth and yield plots in Switzerland. In: Spiecker $\mathrm{H}$, Mielikäinen K, Köhl M, Skovsgaard JP (eds) Growth trends in european forests. Springer, Berlin, pp 239-265

Zscheischler J, Reichstein M, Harmeling S et al (2014) Extreme events in gross primary production: a characterization across continents. Biogeosciences 11:2909-2924. doi:10.5194/bg-112909-2014

Zweifel R, Zimmermann L, Newbery DM (2005) Modeling tree water deficit from microclimate: an approach to quantifying drought stress. Tree Physiol 25:147-156. doi:10.1093/treephys/25.2.147

Zweifel R, Zimmermann L, Zeugin F, Newbery DM (2006) Intraannual radial growth and water relations of trees: implications towards a growth mechanism. J Exp Bot 57:1445-1459. doi:10. 1093/jxb/erj125 